КЛИМАШЕВСКАЯ Ольга Викторовна - кандидат политических наук, доцент Московского авиационного института (национальный исследовательский университет) (125080, Россия, г. Москва, Волоколамское ш., 4; Klimawevskaya@yandex.ru)

\title{
ФЕНОМЕН ГЕНДЕРНОЙ ИДЕНТИЧНОСТИ КАК ИНСТРУМЕНТ ПОЛИТИЧЕСКОЙ БОРЬБЫ ЗА ВЛАСТЬ
}

\begin{abstract}
Аннотация. В статье раскрываются актуальные вопросы использования различных социально-психологических инструментов воздействия на человеческое сознание и мышление и использование как политического инструмента в рамках программы реализации «новых» демократических принципов. Автор анализирует зарубежный и российский опыт, обозначает возможные последствия происходящих в гендерном отношении изменений в обществе.
\end{abstract}

Ключевые слова: гендерная идентичность, половая идентичность, психологический пол, демократия, демократические принципы, права и свободы человека, политическая власть

$\mathrm{B}^{\mathrm{s}}$ о многих странах мирового демократического сообщества предоставление возможности выбора и определения собственной гендерной идентичности для граждан актуализировалось вследствие многообразия политических процессов, таких как институционализация и внедрение в массовое сознание позитивных демократических прав, а также процедур их легализации. Немаловажным моментом стало провозглашение таких ценностей, как свобода и равноправие граждан, возможность выбора гендерной принадлежности, обращение к правам и свободам человека как к высшей ценности, создание политических блоков и организаций, которые являются сторонниками продвижения данных идей.

Еще одним важным фактором для понимания проблемы идентичности человека стал глобальный интерес, связанный с коронавирусом, который представляется и подогревается средствами массовой информации. Эта информационная война с использованием социальных технологий используется как еще один инструмент управления массами. Данные процессы направлены на переформатирование человечества, подразумевающее кардинальную смену образа жизни, образа мышления, осознания и ощущения себя самого. Реализуемый глобальный проект по управлению социумом выражается в том, что новые технологии уже позволяют управлять каждым человеком в отдельности, его идентичностью путем разобщения людей, не позволяя им объединиться для защиты своих интересов.

Гендерная идентичность - эта одна из важнейших форм социальной идентичности человека [Васильева 1999]. Чтобы понять и оценить роль данного феномена в формировании личности в государстве необходимо рассмотреть подструктуры гендерной идентичности. К ним относится половая идентичность и психологический пол. Первая из указанных подструктур представляет собой единство поведения и самосознания индивида, причисляющего себя к определенному полу и ориентирующегося на требования соответствующей половой роли ${ }^{1}$. В этом определении подчеркивается согласованность сознания и поведения человека как представителя определенного пола, т.е. связанность внутреннего психологического компонента и внешнего образа действий. Ориентирами

1 Психология: словарь (под ред. А.В. Петровского, М.Г. Ярошевского). М.: Политиздат. 1990. C. 282. 
для такого согласования выступают биологические факторы принадлежности к тому или иному полу.

Психологический же пол - это комплекс поведенческих, социокультурных характеристик, обеспечивающих индивиду личный, социальный и правовой статус мужчины или женщины [Клецина 2005].

Тем самым в гендерной идентичности как в синтезном феномене на первый план выходят биологические конструктивы, а потом уже на их базе формируются психологические, социокультурные и даже политико-правовые параметры категорий «мужское» и «женское», в соответствии с которыми человек идентифицирует себя с конкретной гендерной группой, конструируя свою идентичность как представитель какого-либо пола.

Повышенный интерес к данной проблеме связан не только с тем, что гендерная идентичность является гибкой составляющей самосознания человека, но и то, что данный феномен обрел политический контекст, преподносимый под вуалью продвижения демократических прав и свобод человека.

Так, ООН определила стратегию содействия гендерному равенству и свободы выбора, согласно которой народы отдельных государств должны пересмотреть их «устаревшие» взгляды на семью, рождение и воспитание детей, образование и признать «альтернативные» сексуальные ориентации такими же нормальными, как и традиционные гетеросексуальные.

Последующий виток свободы определения гендерной идентичности получил новый импульс, когда Западная Европа встала на путь легализации однополых браков. Юридическое признание того, что всегда считалось отклонением от нормы и даже патологией, означает, что данная идеология еще более укрепилась в сознании людей, перейдя от пропаганды и насаждения к легальным процедурам. Абсолютной нормой стало свободное определение своей гендерной идентичности в раннем возрасте и восприятие данного процесса как обыденного явления. Под прямую атаку попали нравственные традиции и моральные принципы, на которых формировались гендерные роли мужчин и женщин, а также институт семьи и брака.

На сегодняшний день политическими решениями во многих странах, таких как Аргентина, Бельгия, Канада, Исландия, Голландия, Норвегия, Португалия, Испания, Швеция, США и др., на государственном уровне было изменено семейное и гражданское законодательство в отношении легализации права свободного определения своей половой принадлежности.

Политические партии, лидеры, общественные организации многих европейских стран понимают, что предложение свободно определять свою гендерную идентичность, преподнесенное в виде развития «новых» демократических принципов, может стать действенным механизмом в борьбе за власть.

Так, в Швеции под давлением проводимой политики за последние 10 лет, начиная с 2010 г., по статистике на $1500 \% 1$ выросло число трансгендеров среди девочек и на $400 \%{ }^{2}-$ среди мальчиков.

В Испании действуют общественные организации, продвигающие гендерное равенство и свободу определения гендерной идентичности. Существует даже Ассоциация мужчин за гендерное равенство. На 2020 г. из 23 членов правительства - 11 женщин-министров, одной из задач которых является не допустить ситуаций ущемления прав и свобод граждан, закрепленных в качестве осно-

1 https://inforuss.info/v-shvetsii-za-10-let-stradayushhih-ot-gendernoj-disforii-vyroslo/ (проверено 10.07.2020).

2 Разрушение полов. Число девочек трансгендеров в Швеции выросло на $1500 \%$. AfterShock. 22.02.2020. Доступ: https://aftershock.news/?q=node/835609\&full (проверено 10.07.2020). 
вополагающих демократических ценностей. Также по состоянию на 2020 г. в правительстве Мадрида действуют 36 агентов по равенству полов, с которыми согласовывают все проекты семейного законодательства. По мнению экспертов и представителей СМИ данного государства, появление подобных должностей и организаций существенно повышает лояльность и политическую активность как женского, так и мужского населения с возможностью свободного выражения своей гражданской позиции и гендерных предпочтений.

В Норвегии даже базируется Институт равенства полов Северных стран, основанный при поддержке Совета министров Северных стран. Данная структура финансирует проекты равных возможностей, помогая в т.ч. политическим партиям реализовывать свои предвыборные программы в части предоставления равных прав и равных возможностей своим избирателям.

Программы российских политических партий и лидеров практически не содержат гендерный контекст продвижения «новых» демократических прав и свобод. На текущий момент российские законы выступают против пропаганды идей о свободе определения гендерной идентичности, против изменения традиционного института семьи и брака. Один из таких законов - федеральный закон «О защите детей от информации, причиняющей вред их здоровью и развитию» - направлен на защиту детей от информации, пропагандирующей отрицание традиционных семейных ценностей ${ }^{1}$. Однако данная ситуация вызывает международный протест. Европейский парламент и Комитет ООН по правам человека осудили Россию и признали законодательство о гражданских, семейных и политических правах нарушающим права человека и ограничивающим свободу выбора. Парламентская ассамблея Совета Европы призвала Россию отменить, в частности, законы о запрете «пропаганды гомосексуализма» и отметила, что такие законы создают атмосферу ненависти граждан друг к другу.

США призвали Россию выполнять обязательства по защите прав человека. Уполномоченный правительства ФРГ по правам человека Маркус Ленинг считает, что подобные законы усиливают «общественную изоляцию представителей гендерных меньшинств и ограничивают свободу мнений». Верховный представитель Евросоюза по иностранной политике, комментируя принятие закона о запрете «пропаганды нетрадиционных отношений» Государственной думой, выразил негативную оценку принятия такого закона и призвала РФ исполнять взятые на себя как страны - члена Совета Европы международные обязательства по обеспечению реализации людьми своих прав по определению гендерной идентичности и защите от дискриминации.

В ООН также считают, что такие запреты в российском законодательстве сужают доступ к соответствующей возрасту информации о сексуальности, которая является важным компонентом гендерной идентичности, а также право на образование и необходимость того, чтобы молодые люди были способны вести полноценный и здоровый образ жизни. На 24-й сессии Совета ООН по правам человека российская делегация отвергла обвинения в дискриминационном характере принятых законодательных запретов, а также отказалась их отменить.

Исходя из сравнительного анализа подходов к легализации данного процесса среди стран, можно выделить следующий блок назревших проблем.

Во-первых, некорректное, а порой губительное воздействие на структурные части гендерной идентичности может спровоцировать негативные последствия в виде различных типов депрессивных расстройств личности, отсутствия

1 Федеральный закон «О защите детей от информации, причиняющей вред их здоровью и развитию» от 29.12.2010 N 436-Ф3 (посл. ред.). Доступ: http://www.consultant.ru/document/ cons_doc_LAW_108808/(проверено 10.07.2020). 
адекватной самооценки и восприятия себя, что существенно снижает качество жизни человека в семье, обществе и государстве. В европейских странах массовый характер стал приобретать синдром гендерной дезориентированности или, как его по-другому принято называть, гендерной дисфории - состояние, при котором человек испытывает дискомфорт или стресс, потому что чувствует, что его гендерная идентичность и биологический пол, определенный при рождении, не совпадают.

Во-вторых, происходит подмена демократических ценностей, которая заключается не в достижении паритетной демократии, обеспечивающей равный доступ к власти и управлению, одинаковое участие в принятии решений мужчин и женщин во всех сферах жизни, а во вмешательстве в личностно-психологическую сферу человека. В качестве субъектов «новой» демократической политики обозначаются заинтересованные структуры власти, которые предоставляют возможность социальным группам и их участникам заявить о свободе выбора своего социально-биологического пола. Внедряя и поощряя на законодательном уровне вышеуказанную стратегию в контексте развития демократии, они разрушают традиционные основы, культурные формы построения института семьи и брака, и, как итог, родители ограничиваются в своих правах на воспитание детей.

В-третьих, государственные концепции стран, где легализовано право на смену пола и право на однополую «семью», стали восприниматься как «великое достижение» демократического устройства. В такой социально-политической среде дети становятся мишенью пропагандируемой нездоровой гендерной идеологии. Покушение на процесс формирования и становления гендерной идентичности личности за счет изменения потоков его сознания фактически программирует человечество на самоуничтожение.

\section{Список литературы}

Васильева Э.П. 1999. Милюска Й. Идентичность женщин и мужчин в жизненном цикле. - Социальные и гуманитарные науки. Отечественная и зарубежная литература. Сер. 11. Социология. Реферативный журнал. № 4. С. 102-114.

Клецина И.С. 2005. Гендерная идентичность и права человека: психологический аспект. - Права человека и проблемы идентичности в России и в современном мире. СПб: Норма. С. 167-184.

\section{THE PHENOMENON OF GENDER IDENTITY AS AN INSTRUMENT OF THE POLITICAL STRUGGLE FOR POWER}

Abstract. The article reveals the urgent issues of using various socio-psychological tools to influence human consciousness and thinking and using it as a political tool in the framework of the program for the implementation of new democratic principles. The author analyzes the foreign and Russian experience and identifies the possible consequences of the genderrelated changes in society.

Keywords: gender identity, psychological gender, democracy, democratic principles, human rights and freedoms, political power 